\title{
The eradication of lung cancer is possible. A biographical note*
}

\section{Renata Furman}

Editor-in-chief of "Służba Zdrowia", Warsaw, Poland

\begin{abstract}
This article is based on a chapter of Renata Furman's book Drogi do Onkologii (Paths to oncology). It outlines a biography of Witold Zatoński, from his childhood, through his years of education, medical studies, and finally his career in medicine, research, and advocacy. The most important part of his professional life (1965-2017) has been devoted to research and prevention activities related to lung cancer and other tobacco-related diseases, as well as the health education of Poles. A rapid growth in smoking prevalence in Poland after the Second World War led to a dramatic increase in lung cancer incidence and mortality, first in men and later in women. Since the beginning of the 1990s, a broad anti-smoking public health campaign in which Zatoński was actively involved (including the Polish Parliament's decision to introduce the 1995 Anti-Tobacco Law) have led to the reversal of smoking prevalence among the Polish population, as well as a decline in lung cancer incidence and mortality, which continues until today. This article relates Zatoński's experiences and observations from this period in Poland's fight against lung cancer. According to The Lancet (13 May 2017-GBD-2015-1) in the years 1990-2015 Poland had one of the fastest smoking prevalence declines in Europe. Similarly, a steady lung cancer mortality decline, also one of the fastest in Europe, was observed in Poland in men from the 1990s and in women after 2000. If current trends continue, optimal conditions for the eradication of lung cancer in Poland can be achieved by the year 2030 .
\end{abstract}

KEY WORDS: public health, health literacy, education, research, smoking, tobacco-related diseases, lung cancer.

ADDRESS FOR CORRESPONDENCE: Witold A. Zatoński, Professor of Medicine, Health Promotion Foundation, 51 Mszczonowska Street, 05-830 Nadarzyn, Poland, phone: +48 2237800 22, e-mail: wazatonski@promocjazdrowia.pl Renata Furman, "Służba Zdrowia", 2 Glogera Street, local 5, 02-051 Warsaw, Poland, e-mail: renata.furman@sluzbazdrowia.pl

\section{WITOLD ANTONI ZATOŃSKI - A BIOGRAPHICAL NOTE}

It was my mother who chose the profession I was to follow. She very much wanted me to be a doctor. She believed it was the best profession that a child could be directed towards in this unstable part of the world and in the complicated, post-war times. It was due to my mother's determination that my two younger brothers and I became doctors.

As we all know, human life is often a question of happenstance. I am a child of war, being born in 1942, with all the corresponding stigmata. I was born close to
Saint Anthony's day, hence my middle name. My parents called me Lucky Anthony. Indeed, in various periods of my life, I had the good fortune meeting exceptional people who shaped my professional path. However, I also inherited from my parents a good intuition which allowed me to make the best of my lucky encounters and the opportunities that presented themselves on my path. The Americans call this an 'opportunistic approach', as opposed to living life according to precise plans. I also think my innate optimism has helped me in my life, in addition to the luck bestowed by St. Anthony. 
Of course, to begin with my life was my family. I spent the first 10 years of my life primarily with my mother. My father, even though he treated his family as the most sacred thing in life (being a very religious man) and loved us very much, right from the beginning of the Second World War, and for many years after it finished, was consumed by his wartime responsibilities and their post-war consequences. My mother was born in the United States. Her parents (grandmother Helena née Zapert and her future husband Józef Łukasik), the children of large peasant families from Poland's Kurpie region, were teenagers when they emigrated to America at the end of the $19^{\text {th }}$ century. It was there that my grandparents met and raised a family. My mother spent the first part of her life in the small New England town of East Hampton, a textile centre near Boston. There she came to know all the good and bad sides of life in exile. After the First World War, the family decided to return to Poland. My grandparents bought a farm close to Brodni$\mathrm{Ca}$, in what was then western Poland. My mother grew up in a beautiful little white house next to the forest. After marrying, she lived with her husband in Warsaw, where my father worked as a manager for Warsaw Railways.

My mother loved Poland with all her heart, although she never spoke about such matters. She proved it and put it into practice in her daily work. As someone born in America, she could easily have obtained the right of residence in the US for herself and her family during the war, but she chose to stay in Poland. My mother's American passport led to her imprisonment by the Germans when the USA joined the war. She spent many months in the notorious Gestapo Pawiak prison. She was forced to take me, her six-week old son, with her to prison. My doctor, Dr. Anna Czuperska, said that I was the youngest prisoner of the Pawiak. The Germans were preparing to exchange their 'American' prisoners for German prisoners of war.

Life did not spare my parents from worries and dramatic events, such as the death of their newborn first son in September 1939, and in 1946 the political murder of my mother's brother Władysław. Post-war political events forced our family to flee to the town of Wałbrzych in the so-called Recovered Territories. There, in 1948, my father was arrested and spent several years in a Stalinist prison. My mother had to bring up two children alone, in a completely new and alien environment.

A month before my father's arrest, at the age of six, I started school. I was lucky to get a place in a very good school, imbued with the atmosphere of pre-war Lwów (the school is described in the book Ocalic od zapomnienia [To save from oblivion. Reunion diary 2005. Sixty years of Wałbrzych's High School No. 1, celebrating the school's eightieth anniversary, Wałbrzych 2005]). Located just a few steps from where we lived, this school became my second home. My mother, who to begin with had problems finding a job, and then worked from dawn to dusk in Szczawno-Zdrój, about five kilometres from Wałbrzych, found solace in the solidarity of her family and neighbours, and the friendly atmosphere of her children's school, which provided my brother Irek, two years my junior, and myself a fruitful education. We lived a pretty meagre existence - my basic meal was sometimes just bread with a sprinkling of sugar.

Of course, this situation also shaped our characters. I spent all my free time practicing sports with great zeal. I lived close to school, but still closer to the beautiful sports stadium in the Wałbrzych New Town. In my childhood sports was the most important thing to me, and my sporting successes were the source of greatest joy for me. I practiced all possible sports: of course football, but also athletics (especially the high jump) and basketball.

It may have been my mother who chose what I was to study, but it was with my approval. I had absolute confidence in the wisdom of her decisions. In addition, the subjects that I had to pass in order to get into medical school were in line with my interests. I enjoyed chemistry very much, and in school joined a chemistry club. My first photo, which appeared in a Wałbrzych newspaper, showed me standing with a flask and a pipette in a chemistry lab. My teacher claimed that if I were to take the exams for chemistry, I would pass with flying colours, but doubted I could ever be a medical student. Back then, it was very difficult to get into medical school. Nor did I warrant any extra points from the admissions system for being from a working-class background. I treated the medical examinations as a challenge. My parents were very much involved in preparing me for the competitive exams, as if it were the most important sports match in my life so far. We spent a whole 6 months in preparation. I had a private tutor, and before the exam I went with my mother to Wrocław, where we lived with friends of my parents. This meant I was able to take advantage of preparatory courses organized by the Medical Academy. And although I was not the best student in the class, and many of my school friends also took the medical exams, I was the only one in the whole school to win a place in the Academy. This was July 1959, one month after my $17^{\text {th }}$ birthday. I was the first person in the family to go to university. I helped pave the way for my two younger brothers, who also graduated as doctors from the Wrocław Medical Academy.

Already at the first lecture I was elected the student representative for our year. As it turned out, that was to be one of the most important elections in my life. I won entirely by accident. With no rational explanation. Nobody knew me. I was slim and tall. I won in an open ballot of several hundred first-year students. It was a huge responsibility and commitment, but it also afforded me extraordinary opportunities. I did my job well, as proven by the fact that I won all student elections by a large majority. I was popular. I didn't realize then how 
much that would affect my life. Throughout my studies, as a student representative I had regular contact with professors, but also with the university's administration - the rector, dean and so on. I participated in decisions regarding students. I automatically joined the student government of our Academy, and later the intercollegiate student government.

Wrocław was a huge university town and I became part of a large research and education establishment. To begin with, I didn't realize in what an priviliged position I had found myself in, surrounded by exceptional people. When I was elected student representative, I didn't know that I was about to study and then work in historically one of the most outstanding universities in Europe - a university that could boast ten Nobel Prize winners. In the second half of the nineteenth and first half of the twentieth century, Wratislavia (Breslau) as it was then called, was a cosmopolitan powerhouse in the world of medical science. The famous names to have worked at and helped create this medical academy included Robert Koch (the discoverer of anthrax), Albert Neisser (see Neisseria gonorrhoea), Alois Alzheimer (see Alzheimer's disease), or the brilliant abdominal surgeon Jan Mikulski-Radecki, as well as Ludwik Rydygier and a little earlier, Jan Evangelista Purkyně (after whom the subendocardial fibres are named). And one especially dear to me today, born in Strzelin, a graduate of the University of Wrocław, Doctor Paul Ehrlich (Nobel Prize winner), pioneer of immunology, and the discoverer of chemotherapy. A hundred years ago, he began researching cancer immunology - probably the most appropriate way to treat cancers. Perhaps at the beginning of the $21^{\text {st }}$ century Ehrlich's research, begun more than a century ago, will solve the problem of how to treat cancer patients. Finally, before the Second World War, Prof. Karl Heinrich Bauer, founder of the German Centre for Research on Cancer (Deutsches Krebsforschungszentrum) in Heidelberg, was also educated and worked in this university, where I was to work for many years.

Wrockaw's scientific traditions survived the cataclysm of war, although that is little short of a miracle. On November $15^{\text {th }}, 1945$, the inauguration of the first academic year took place in the baroque Leopoldin Hall. The inaugural lecture was delivered by the Dean of the Medical Faculty, Professor Ludwig Hirszfeld - a worldclass scholar and physician and great human being. Born in Warsaw, educated at the best German universities, in the interwar period he was Director of the National Institute of Hygiene in Warsaw.

Most of our professors came from the Jan Kazimierz University of Lwów ${ }^{1}$, the rest - from many different cities around the country. At the same time Wrocław's Medical School, by way of its history, equipment and infrastruc-

'Unfortunately, the most eminent professors in Lwów had been murdered in July 1941 by the Gestapo; among those killed was the physician Professor Roman Rencki, the teacher and master of Antoni Falkiewicz. ture, became the continuation of one of the most important medical schools in Europe - the pre-war German University of Breslau.

The Medical Faculty was housed in the buildings of the old Breslau Medical University. At the beginning of the 1960s, when I began studying in these halls of learning and hospitals - temples of medicine and science - it seemed that the spirit of scientific achievement had come down through history and was ever present. For several decades, this both new and old Medical Academy became one of the leading medical centres in Poland, both in terms of scientific research and the training of young physicians. Among our teachers there were international, European and Polish celebrities of science and medicine. Antoni Falkiewicz and Edmund Szczeklik, Bożena Zarzycka, Hugon and Zofia Kowarzyk, Janina Bogusławska-Jaworska, Bogusław Bobrański, Zygmunt Albert, Stefan Ślopek, Janina Kwiatkowska, and Feliks Wąsik. The Wrocław Medical Academy collaborated closely with the brilliant mathematician from Lvov and Wrocław, Professor Hugo Steinhaus. The professor had a particularly close relationship with the doctors. The Wrocław Scientific Society founded by him was an important scientific centre (many of my first research papers were published in the society's pamphlets). In the 1960s, six ordinary members of the Polish Academy of Sciences worked in the Wrocław Medical Academy, a disproportionately large contingent for one university.

The first years of medical studies are dedicated to basic sciences. In my case biochemistry was the natural choice. The Medical Academy in Wrocław taught us not only the profession but also scientific skills. The university had a very strong cadre of biochemists. In 1950, the head of the Biochemistry Department was Tadeusz Baranowski ${ }^{2}$, a colourful and interesting figure and a student of Professor Jakub Parnas of Lwów, one of the world's greatest biochemists before World War II, murdered by Stalin several years after the war.

Baranowski had numerous foreign contacts - in his time working with Carl Ferdinand Cori and his wife Gerta, Nobel Prize winners in physiology and medicine. It was even said that Baranowski had come close to winning the Nobel prize himself. In the years 1938-1939, he was the first scientist in the world to crystallize protein. For us he was a worldly figure, who dressed quite eccentrically - he wore a large, shiny bow tie beneath his chin, and drove the latest Mercedes - a $180 \mathrm{D}$. He fascinated me as a person, although contact with him was not easy. He was the aloof scientist type, but always kind to me. As the representative for our year, I had direct contact with

${ }^{2}$ As early as 1939, Tadeusz Baranowski, at the famous Lwów biochemical school, conducted work on the crystallization of proteins and planned their X-ray examinations. His work was interrupted by the war. In 1942, when he worked in the United States with Carl and Gerti Cori, he isolated and described phosphoglycerol dehydrogenase, called the Baranowski enzyme. His work on molecular biology formed the basis of this field of research 
him. This way Professor Baranowski became my mentor. After some time, he offered me a job as a research volunteer in his department. My immediate tutor was Dr. Janina Korczak-Kwiatkowska. At the end of my studies, Professor Baranowski offered me the position of assistant to the Chair of Biochemistry. I had won my spurs as a scientist. This environment of biochemists taught me scientific thinking and skills, and helped to define my interests. The first works that I published shortly after my studies were prepared in the Biochemistry Department with Professor Baranowski and his colleagues ${ }^{3}$. I began to conduct my own scientific experiments, developing an interest in molecular biology. Professor Baranowski was also an extremely important person in shaping my position at the university - for some time he was the Rector of the Medical Academy. I also served a public function as secretary of the Medical Academy's next Rector - the outstanding laryngologist Professor Stanisław Iwaszkiewicz.

In my third year of studies, my medical education also included clinical subjects. There I met many eminent physicians. I was very interested in medical diagnostics. Among other things, the Wrocław Medical Academy established an excellent school of internal medicine. Its most important representatives were Antoni Falkiewicz, my later mentor, and Edmund Szczeklik, with whom I took up a 6-month internship after completing my studies. These scientists after the Second World War created the Polish school of internal medicine, and their students (Gibiński, Tkaczewski et al.) went on to head many of the internal medicine clinics at medical faculties around Poland. No. 4 Pasteur Street in Wrocław (Szczeklik's clinic was on the ground floor and Falkiewicz's on the first floor) housed the most important centre for internal diseases in Poland. Wrocław also boasted one of the best operating theatres in Poland. One of the country's greatest cardiac surgeons was Professor Wiktor Bross, who on February $12^{\text {th }}, 1958$ performed the first open heart surgery in Poland.

My contacts and organisational and managerial skills gained in the student government were useful in the creation of a Red Blood Cell Metabolic Research Laboratory, which we managed to launch in a short space of time. Thus, I worked in the clinic and at the same time ran a scientific laboratory. This, of course, increased not

Zatoński W, Kwiatkowska J, Baranowski T, Tawlas N. Badania nad aktywnością enzymów glikolitycznych erytrocytów w czerwienicy prawdziwe (Materials for the $9^{\text {th }}$ Congress of the Polish Haematology Society, Wrocław, October 9-11th 1969, the whole of this material was published in Issue No. 1 of "Acta Haematologica Polonica" in 1970; the English version appeared under the title "Investigations on the activity of glycolytic enzymes in poly cythemia vera" in Issue No. 10 of the Polish Medical Journal in 1971); Kwiatkowski J, Zatoński W, Baranowski T. Zmiany właściwości fosfofruktokinazy krwinek czerwonych w czerwienicy (Materials for the 9th Congress of the Polish Biochemical Society, Katowice, September 8-11 $1^{\text {th }} 1971$; the English version appeared under the title "Erythrocyte phosphofruptokinase alterations in polycythemia vera" in Issue No. 40 of "Clinica Chimica Acta" in 1972 and also under the title "Erythrocyte phosphofruptokinase and glucose-6-phosphate dehydrogenase in leukemia" - "Fosfofruktokinaza i dehydrogenaza glukozo-6-fosforanowa erytrocytarna w białaczce" in Issue no. 45 of "Clinica Chimica Acta" in 1973). only my prestige, but also my possibilities. I became an increasingly interesting partner for biochemists, even eminent researchers.

In addition, along with my direct supervisor, Professor Roman Smolik, and my colleague - now a professor - Andrzej Lange, I succeeded in expanding the research population. We began conducting epidemiological observations among large professional groups in such industrial centres as the Świdnica Wagon Factory, the Industrial Installations Works in Nysa, the Lubin Copper Basin, the Lower Silesian Asbestos Seals and Products Plant in Gryfów Śląski, and so on. I also participated in population-based studies of goitre and hypertension among the inhabitants of Lower Silesia, conducted over many years by Professor Antoni Falkiewicz.

After completing my studies, I started a two-year clinical internship, but at the same time continued the scientific research I had begun during my studies in Professor Baranowski's biochemistry department. I created a methodology for tissue testing, a biochemical "biopsy", the biochemical characteristics of human red blood cells that were my model. Following my clinical internship, I was accepted by Professor Antoni Falkiewicz to work as an assistant in Wrocław Medical Academy's Department of Internal Diseases. I considered internal medicine the most important specialty, the queen of medical science. For 20 years I worked intensively as a clinician at my Alma Mater. In 1970 I passed the exam for the first degree of specialization, and in 1974 became a second-degree specialist in internal medicine. At the same time, in 1973, I earned a doctorate. For my doctoral thesis I was awarded the Scientific Council Award by the Minister of Health. It was presented to me by Professor Witold Rudowski, an icon of Polish medicine, who was the Council's Chairman at the time. A few years later, in 1978 I earned a postdoctoral degree, also in the field of internal diseases. This all happened while still at the Medical Academy in Wrocław. I was 35 years old.

In parallel with my professional career was the medical work, perhaps the most important in the Wrockaw period. I had a good "clientele". My most famous patient was the poet Tadeusz Różewicz, with whom I became friends. I treated mayors of Wrocław, provincial governors, important scientists and artists but above all, ordinary people of all possible professions. These patients often became my friends. I am physician to some of them to this day. Our clinic was primarily an ordinary hospital, treating 24 hours a day all the patients who came to us.

This intensive work with patients lasted about 20 years. Naturally, all these years at the bedside of patients led to many observations and conclusions. One of them was our helplessness in the face of cancer, with no chance of a cure. In the 1960s, cancer was considered one of the symptoms of old age, like grey hair or liver spots. The largest group of cancer patients in our clinic were those 
with stomach cancer. We made various attempts to treat them, some very controversial. Our master, Professor Falkiewicz, a critical rationalist, opposed any suggestions of "medical tricks". He knew that medicine was a science, not art. When Professor Tołpa tried to treat stomach cancer on an outpatient basis with turf formula, as soon as it became apparent that patients were dying just as they had before, Professor Falkiewicz forbade the use of this method in the clinic.

My observations of tumours mainly concerned lung cancer. During the first ten years of my medical career, I composed an annual summary of my own patients: the number of lung tumours diagnosed by me at that time increased many times over. In my internal medicine practice, this was the fastest growing disease group, after heart attacks. The causes of lung cancer seemed very puzzling. It was said that it occurred among smokers, but back then everyone smoked, even the vast majority of my colleagues. One could suffocate from the fumes during our morning meetings in the assistants' room at the Wrocław Medical Academy's Internal Diseases Clinic No. 2. No one was interested in lung cancer. Once diagnosed, patients were usually referred to the lung disease clinic. I often asked my colleagues about those patients - their survival times were short. Physicians treated lung cancer as a terminal illness.

While still working towards my post-doctoral degree, I won a competition for a prestigious Humboldt scholarship and went to Heidelberg. I was still hesitant about continuing my work in experimental molecular biology labs. I spent the first two months in Hamburg at the Institute of Basic Sciences, but decided against staying longer. I decided to devote myself to cancer epidemiology and so chose to move to the German Cancer Research Centre in Heidelberg. In this way I began - though I didn't realize it then - a new chapter in my life: cancer research.

That decision was also the result of my professional experience. At the clinic of Professor Falkiewicz and his deputy, Professor Roman Smolik, we conducted largescale population studies. We wanted to understand how exposure to various toxic - especially carcinogenic - factors in the work environment affected the functioning of the body. For instance, we studied people exposed in the workplace to such carcinogens as benzene, asbestos and radon. We attempted to explore whole cohorts of professional people to understand what was happening in the human body under the influence of harmful, carcinogenic factors. Already - though I didn't know it yet - I was just a step away from research into the health effects of smoking and exposure to carcinogenic substances in tobacco smoke.

When I found myself in Heidelberg, I was already well-educated both as a physician and in terms of my scientific skills. There, in the German Centre for Cancer Research (Deutsches Krebsforschungszentrum), my interests turned more and more towards epidemiology, and the population dimension of health. I met a group of researchers who were investigating the causes of carcinomas and their geography, the spread of this disease and its causes around the world. There I also met Dr. Calum Muir, a Scotsman and a physician with a remarkable biography. He was the Deputy Director the International Agency for Research on Cancer (IARC-WHO Lyon), who occasionally visited Heidelberg. We spent many hours discussing the roots of cancer and their place in the pathology of the human body. This encouraged me to become more deeply involved in epidemiology, and establish one of the centres of international epidemiology in Poland.

Together with Sir Richard Doll ${ }^{4}$ and William Henschel from the National Cancer Institute (NCI) in Bethesda, whom I met later, Muir formed a network of epidemiological groups in various parts of the world. This was because initially, the frequency and geography of malignant tumours around the world was seen as a way of understanding the mystery of their occurrence. Back then, there was a great geographical variation in the incidence of cancer, and its causes were looked for in racial differences. Cervical cancer was the main type of cancer in Latin American women; stomach cancer was most common in Japan, and also very common in Poland. Lung cancer was most common in the United Kingdom and the United States. Throat and laryngeal cancer was most common in the Mediterranean countries of Europe, mainly in France and Italy, but was also frequent in Iran and China. Skin cancer, melanoma, was most common in Australia. In Central European countries - Poland, Hungary, and the Czech Republic, the incidence of gall bladder cancer was high in women. There was a strong conviction that there were some specific factors involved in the fact that tumours occur in such a distinctive way in different parts of the world. That's why an attempt was made to build a team of people working in different parts of the world, but using the same common methods of comparative research. Muir strongly urged me to become an epidemiologist and conduct work on the aetiology of cancers in Poland. He introduced me to Professor Tadeusz Koszarowski, the Director of the Institute of Oncology in Warsaw and at the same time Director of the Oncology Centre, then under construction. Professor Tadeusz Koszarowski was then building the infrastructure and recruiting the medical and scientific staff for the Oncology Centre, which was to be ready for the $50^{\text {th }}$ anniversary (1932-1982) of the founding of the Skłodowska-Curie Radium Institute in Warsaw.

Although he didn't know me at all, Professor Koszarowski gave me a job in Warsaw, relying solely on Muir's recommendation. The professor also organ-

${ }^{4}$ The creator of global epidemiology (population-based case-control study on human health) and cancer registers, who in 1948-1951 explained the riddle of lung cancer. 
ized a place for me to stay in the capital. At that time, construction was just being completed on the Oncology Centre in the Warsaw suburb of Ursynów, and I became its first tenant. Koszarowski provided me with the use of two tiny rooms in the part of the building which now houses the outpatient clinic. I basically lived on a building site. When I arrived home for the night, construction workers were still around and I had to put on wellies to reach my apartment.

I left Poland as a clinician and came back as an epidemiologist. When I was leaving Wrocław for Heidelberg on the Humboldt scholarship, I hadn't intended to later change my job or profession. But finally, Calum persuaded me to take up epidemiology in Poland and become part of the international cancer research team. In November 1979, I became an employee and, after some time, a docent of the Oncology Institute in Warsaw. It was the central organization for cancer research and treatment in Poland. I was to be concerned mainly with the epidemiology of cancer and organizing cancer control activity. The long-term goal was to reduce the incidence of cancer in Poland.

Professor Tadeusz Koszarowski gave me a considerable degree of professional and scientific freedom. For some time, he himself was involved in epidemiological studies and with colleagues from our branches in Kraków (Professor Hanna Kołodziejska-Wertheim) and Gliwice (Professor Jerzy Staszewski) created cancer registers. He allowed me to formulate and conduct research and cancer prevention and intervention by myself. He supported my additional collaborations and approved extra commitments. It seems that during this period of my professional development, he was the ideal supervisor. His only goal in both his professional and personal life was oncology. He had a sense of mission: to continue the work of Maria Skłodowska-Curie and her sister, Bronisława Dłuska, who founded the Radium Institute in Warsaw in 1932. In the mid-1970s, he began a new stage (on a very large scale) in the development of Polish oncology. He oversaw the building of a huge clinical and scientific centre. From the mid-1970s he also conducted the National Oncology Program PR 6. I enjoyed Professor Koszarowski's full confidence and he was always ready to help; although sometimes he worried whether I was really planning to stay in the Centre forever, or whether I just preparing for a future in the West. I don't think I disappointed him. I worked there from 1979 to November $2016^{5}$.

${ }^{5}$ Unfortunately, the good relations I had enjoyed with Tadeusz Koszarowsk and his students - Jan Steffen, Andrzej Kułakowski and Marek Nowacki were not to be had with the next 'imported' directors, who had little vision or feel for oncology compared to their predecessors, although it cannot be denied that they were intelligent, diligent and crafty. At the beginning of the new century, together with the above-mentioned Jan Steffen, Andrze Kułakowski and Marek Nowacki, we prepared the successful National Cancer Control Program that came into force in 2006 and covered the years 2006-2015
Following my appointment, the professor assigned me two assistants and a secretary. Our group was accommodated in two small rooms in the so-called Little House on Wawelska Street ${ }^{6}$. In the final period of my scientific residency in Heidelberg, the Humboldt Foundation made the remarkable decision to help fund the construction of a scientific laboratory for the international scientific research I was planning in Warsaw. I received 150,000 dollars for this purpose. This was an enormous donation. Professor Koszarowski was also extraordinarily committed to the idea and provided an equal sum from the funds of the Count Jakub Potocki Foundation. This meant for instance that we were able to purchase what was then one of the best computers in the world, PDP-11, for my laboratory. This enabled me to create electronic cancer databases based on my research (so-called Big Data) and computerize cancer registration in Poland. The introduction of the PDP-11 to Poland was also accompanied by some problems: there was an embargo on the import of large computer units into Communist countries, as such hardware was also ideally suited to other purposes, such as missile control. We had to organise a special permit, and I was required to sign a commitment that only I would use this computer. And so, equipped by the Humboldt Foundation and Professor Tadeusz Koszarowski with an epidemiological laboratory, I was able to start building a cancer epidemiology and prevention unite in Poland.

My first goal in the early 1980s was to set up an epidemiological diagnosis of cancer in Poland and a program of public health activities aimed at monitoring and reducing cancer rates. Today this would be called a 'roadmap' of tobacco control in Poland. I published two monographs on carcinomas in Poland: the first in English in cooperation with Nikolaus Becker, a mathematician from the German Cancer Research Centre in Heidelberg. Harald zur Hausen, later a Nobel Prize winner, and the Director of the Oncology Centre in Warsaw Professor Jan Steffen, wrote the introduction to that publication. The book, in English, was beautifully published, with maps and charts, by Springer-Verlag, one of the most important scientific publishers [1]. The monograph was highly rated and to this day I myself sometimes turn to it. A few years later I published another monograph on the epidemiology of cancer in Poland, this time in Polish [2]. Having a ready diagnosis and 'roadmap' for public health in Poland, I was able to concentrate on interventions.

It was early during my time abroad that I learned that the mystery of the lung cancer epidemic had already been resolved for some time. I received information

${ }^{6}$ It was here too, in November 2016, that I retired. However, in the busiest periods of my professional career at the Centre, I was managing teams of more than hundred people, which carried out programmes of cancer registration, epidemiology, and primary and secondary prevention. For a long time, my team was based in a building of the Oncology Centre in Ursynów and in the so-called Cancer Prevention Centre. 
first hand, directly from Richard Doll and his colleague Richard Peto. In 1950, Professor Sir Richard Doll and his team carried out a cohort study of 35,000 British doctors. After a year of observation, they were extremely surprised to find that in this cohort, lung cancer occurred almost exclusively among cigarette smokers. The cigarette industry however, had enormous power and skilfully repudiated these scientific reports, and the public proved so helpless and unorganized that when I commenced my crusade against smoking in Poland in the 1980s, many politicians claimed that my talk of the drastic effects of inhaling tobacco smoke was a load of nonsense. It was thought that I exaggerated the carcinogenic effects of exposure to cigarette smoke and that, as far as lung cancer was concerned, environmental pollution, occupational exposure and a hundred other factors were more important causes.

At the time, awareness that lung cancer is almost exclusively found among cigarette smokers was widespread in Western Europe. In countries where the lung cancer has previously been endemic, i.e. the United Kingdom and the United States (the peak of the disease in the United Kingdom occurred in the late 1940s and in the United States in the early 1950s), this was followed by a fairly rapid drop in lung cancer incidence. This was due to a decrease in the prevalence of smoking, in other words exposure to cigarette smoke. These positive developments were partly the result of vibrant anti-smoking campaigns in both countries. In other words, the British and Americans not only discovered the cause of lung cancer among smokers, but also the way to eradicate the disease. One of my professional idols and associates, Sir Richard Peto, advised me in the 1980s that if I wanted to see the fruits of my medical work during my lifetime, I would have to repeat in Poland what had taken place in tobacco control in the UK and USA. And that's just what happened.

At first, however, in the 1980s, I focused primarily on building up the field of cancer epidemiology in Poland. For six months I worked in London, in one of the best epidemiological schools in the world - the London School of Hygiene \& Tropical Medicine. Then I spent six months in Lyon at the International Agency for Research on Cancer (IARC), where I and Calum Muir set up the research program I was to conduct in Poland. My first population survey in Poland concerned laryngeal cancer. The research hypothesis I was to test stemmed from Muir's observations. While studying the distribution of carcinomas in the world (he was a co-editor of the cyclical IARC WHO publication "Cancer Incidence in Five Continent"), he noted that the incidence of laryngeal cancer is particularly high in Poland, and that it is forty times higher in men than in women. In Poland, this sex ratio for cancer of the larynx was the highest in the world. My research, a population-based case-control type study, was based on data concerning the incidence of laryngeal cancer among residents of Lower Silesia. I conducted this analysis together with the laryngologist Professor Stanisław Iwankiewicz, Rector of the Wrocław Medical Academy. My first epidemiological study was published in the prestigious scientific journal Cancer Causes and $\mathrm{Control}^{7}$ as a "number one".

Professor Koszarowski and his staff (especially Professor Jerzy Staszewski) had good working contacts with the American National Cancer Institute (NCI) in Bethesda. I took advantage of these already well established contacts with the United States. The first tasks I received from Tadeusz Koszarowski included the preparation of a scientific program of long-term cooperation with the National Cancer Institute in the field of epidemiology and primary prevention. This was an enormous challenge. Fortunately my American student from Wrocław, John Junior ${ }^{9}$ (now my friend, and a doctor in the USA), agreed to dedicate a month of his student vacation to assist me. I then started working with the Americans and have done so to this day. My trusty partners for many years have been John Fraumeni, Bethesda's longtime Director of Epidemiology, Bill Blot, Jenny How, Linda Britton, Alexander Walker, Walter Willett, Jonathan Samet, Tom Novotny, Tom Glynn and many others. Together we conducted a lot of important research, one of the most significant being our study on the aetiology of stomach cancer, which at that time was one of the most common malignant tumours in Poland, but already extremely rare in the United States. Our research with Bill Blot has earned a permanent place in the history of stomach cancer. We also began a series of tests on breast cancer in women. These studies are conducted on a large scale to this day. We are continuing our research activities in cooperation with international teams; previously our partners were organizations setting up cancer registers: investigating particular carcinomas using molecular biology techniques. Every year we publish a considerable number of research papers.

In my work, however, I return with increasing frequency to the question of lung cancer, and reducing its threat to the Polish population has become my primary professional goal. As early as the 1980s, I began to work on improving the competence of the Polish medical profession in this field. At first, my efforts to engage politicians in effectively combating smoking, the only

${ }^{7}$ In the second decade of the $21^{\text {st }}$ century, my Hirsch index was 50 , and the number of quotes amounted to over 10,000

${ }^{8}$ The reason for the frequent cases of laryngeal cancer in Poland turned out to be simple. Malignant cancers of the larynx, especially those localized in the epiglottis, occur almost exclusively in the population with extremely high exposure to alcohol and cigarette smoke (active smoking). Laryngeal cancer develops many times more frequently in those who smoke a lot and drink daily or almost every day. The article referred to is: W. Zatoński, H. Becher, J. Lissowska, J. Wahrendorf: "Tobacco, alcohol, and diet in the aetiology of laryngeal cancer: a population-based case-control study" (Issue No. 2 of "Cancer Causes Control", 1991).

${ }^{9}$ Bill Henschel, Deputy Director of the National Cancer Institute, co-founder of global cancer epidemiology, the global network of cancer registers, later asked Professor Tadeusz Koszarowski where had the Institute suddenly found a fellow who spoke such good English. 
way to eliminate lung cancer, failed to produce significant results. But as our political system changed things begun to move faster, with new possibilities opening up. It turned out that democracy is healthier.

In November 1990, together with the American Cancer Society and the Union for International Cancer, we organized a large international conference in Kazimierz nad Wisłą, Poland. Already at the preparatory stage, this event received wide media coverage. We received letters of support from Lech Wałęsa and Jimmy Carter, and a little later from Bill Clinton and Pope John Paul II. It was at the Kazimierz Conference that I became truly involved in public health, and in a sense, in politics. I turned from being purely a scientist into a person trying to put his theoretical knowledge into practical use.

I established the Health Promotion Foundation, which basically had one goal: to secure the adoption of a law limiting the health effects of smoking. I have been helped in my crusade by some wonderful people, including the politicians Seweryn Jurgielaniec, Maciej Krzanowski, Jerzy Matyjek, Andrzej Wojtyła, and many other parliamentarians and thousands of celebrities and ordinary people who understood the meaning of my efforts. The Catholic Church played a special role here. From 1992, Primate Cardinal Józef Glemp was the honorary president of our foundation. And each year Poles who had quit smoking participated in private audiences with the Pope, which took place in the Vatican until John Paul II's death. Our campaign, called the Great Polish Smokeout, is considered one of the most effective public health campaigns of the 1990s in Europe. I refer any readers interested in the history of this venture to my book Droga do zdrowia (Road to Health). A history of combating the epidemic of tobacco diseases in Poland (published by the "Health Promotion" Foundation, Warsaw 2004).

When I look today at the data showing that at the end of the 1980s, 101 billion cigarettes were sold in Poland, and at the moment that figure is only about 40 billion; that back then more than $60 \%$ of adult men and $30 \%$ of adult women smoked, and the current figures are less than $25 \%$ of adult men and about $18 \%$ of women; I can say that we are winning this war (see Hundred years of cigarette smoking in Poland: three phases of the tobacco epidemic, pp. 118-123).

Already by the late 1990s, when this downward trend was first noted, there was no longer any doubt about the importance of this shift. The incidence and mortality of lung cancer in Poland had begun to decrease. This marked the end of the first stage of my struggle with lung cancer in Poland. Not only did the diagnosis prove correct, but also the intervention was working. I realised that 'it can be done'. The speed at which the health indicators improved came as a big surprise to everyone, including us. When we first presented our observations of this improvement in the mid-1990s, they were met with incredulity. However, we made sure to mon- itor and quantify the changes closely in order to avoid the phenomenon of 'invisible prevention'. Lung cancer incidence among middle-aged men (35-54) declined in Poland between 1990-2000 by 2000 cases per annum. This translated into a decrease of lung cancer mortality rates in this group from 60 deaths per 100,000 to nearly $40 / 100,000$. These numbers constituted hard, indisputable facts which showed to the politicians, but also to the broader public, the real value of well-conducted, systematic, and persistent public health efforts and prevention. The attitudes towards tobacco changed, and every year around $30 \%$ of smokers attempted to quit. Effective treatment of tobacco addiction became the key challenge on the path to the eradication of lung cancer. Tobacco control in Poland entered the next stage.

\section{DISCLOSURE}

Author reports no conflict of interest.

\section{References}

1. Aaro LE, Mazur J, Zatoński WA, Samdul O. Trends in smoking among Polish and Norwegian youth 1986-2014. J Health Inequal 2016; 2: 44-51.

2. Becher H, Zatoński W, Jockel H. Passive smoking in Germany and Poland: comparison of exposure levels, sources of exposure, validity and perception. Epidemiology 1992; 3: 509-514.

3. Blanke DD, de Costa e Silva V. Tools for advancing tobacco control in the $21^{\text {st }}$ century. Tobacco control legislation: An introductory guide. World Health Organization, Geneva 2004.

4. Boyle P, Boffetta P, Lowenfels AB, Burns H, Brawley O, Zatonski W, Rehm J. Alcohol. Science, Policy and Public Health. Oxford University Press, Oxford 2013.

5. Boyle P, Gray N, Henningfield J, Seffrin J, Zatonski W. Tobacco. Science, Policy and Public Health. Oxford University Press, New York 2013.

6. Boyle P, Maisonneuve P, Bas Bueno De Mesquita H, Ghadirian P, Howe GR, Zatonski W, Baghurst P, Moerman CJ, Simard A, Miller AB, Przewozniak K, McMichael AJ, Hsieh CC, Walker AM. Cigarette smoking and pancreas cancer: a case-control study of the SEARCH programme of the IARC. Int J Cancer 1996; 67: 63-71.

7. Chow W-H, Swanson CA, Lissowska J, Groves F, Sobin L, Nasierowska-Guttmejer A, Radziszewski J, Regula J, Hsing A, Jagannatha $S$, Zatonski W, Blot W. Risk of stomach cancer in relation to consumption of cigarettes, alcohol, tea and coffee in Warsaw, Poland. Int J Cancer 1999; 81: 871-876.

8. Connolly GN. Tobacco, trade and Eastern Europe. In: Tobacco and health. Slama K (ed.). Plenum Press, New York 1995.

9. Czuperska-Śliwicka A. Cztery lata ostrego dyżuru. Wspomnienia z Pawiaka 1940-1944 [Four years of sharp duty. Memories from Pawiak 1940-1944]. Warszawa 1989.

10. Diehl J. Poles refuse to put out their cigarettes. The Washington Post, February 10, 1987.

11. Doll R, Peto R, Bjartveit K, et al. Tobacco and death in Eastern Europe. In: Cancer prevention in Europe. Bodmer W, Zaridze D 
(eds.). Organization of European Cancer Institutes, London 1993; 71-97.

12. Fagerström KO, Boyle $P$, Kunze M, Zatoński W. The anti-smoking climate in EU countries and Poland. Lung Cancer 2001; 32: 1-5.

13. Fagerstrom KO, Kunze M, Schoberberger R, Breslau N, Hughes JR, Hurt RD, Puska P, Ramstrom L, Zatonski W. Nicotine dependence versus smoking prevalence: comparisons among countries and categories of smokers. Tob Control 1996; 5: 52-56.

14. Feachem R. Health decline in East Europe. Nature 1994; 367: 313-314.

15. GBD 2015 Tobacco Collaborators. Smoking prevalence and attributable disease burden in 195 countries and territories, 1990-2015: a systematic analysis from the Global Burden of Disease Study 2015. Lancet 2017; 389: 1885-1906.

16. Gilmore A, Zatoński W. Free trade versus the protection of health - How will EU accession influence tobacco control in Poland? Eurohealth 2002; 8: 31-33.

17. Herbeć A, Janik-Koncewicz K, McEwan A, West R, Zatoński WA. Development and evaluation of STAR - an expert digital platform supporting training and delivery of cessation interventions by healthcare professionals in Poland - Project overview. J Health Inequal 2017; 2: 133-137.

18. Hertzmann C. Environment and health in Central and Eastern Europe. World Bank, Washington DC 1995.

19. Jha P, Peto R, Zatoński W, et al. Social inequalities in male mortality, and in male mortality from smoking: indirect estimations from national death rates in England and Wales, Poland, and North America. Lancet 2006; 368: 367-370.

20. Kubik AK, Parkin DM, Plesko I, et al. Patterns of cigarette sales and lung cancer mortality in some Central and Eastern Europe countries, 1960-1989. Cancer 1995, 75: 2452-2460.

21. Mahood G. Warnings that tell the truth: breaking new ground in Canada. Tob Control 1999; 8: 356-362.

22. McKee M, Zatoński W. How the cardiovascular burden of illness is changing in eastern Europe. Evid Based Cardiovasc Med 1998; 2: 39-41.

23. McMichael AJ, Zatoński W. Environmental, behavioral, and socioeconomic influences: tackling the historical jigsaw puzzle of health in Central and Eastern Europe. Int J Occup Environ Health 1996; 2: 161-163.

24. Michaels D. Targeting Poles who smoke like chimneys: Activists make headway in fight against tobacco use. The Wall Street Journal 1999; April 8.

25. Murray C, Lopez A. Global and regional cause-of-death patterns in 1990. Bulletin on the World Health Organization 1994; 72: 447-480.

26. Pamiętnik Mary Berg. Relacja o dorastaniu w Warszawskim Getcie [Report on growing up in Warsaw Ghetto]. Prószyński i S-ka, Warszawa 2016

27. Paniccia R. Economic shocks, impoverishment and poverty-related mortality during the Eastern European transition. Working papers 126 . The United Nations University/World Institute for Development Economics Research, 1997.

28. Patel T. Eastern Europe heads for smoking catastrophe. New Scientist 1994; 1948. Available from: https://www.newscientist.com/article/mg14419481-400-eastern-europe-heads-forsmoking-catastrophe/ (accessed: 2 October 2017)
29. Perlez J. Fenced in ear home, Marlboro man looks abroad. The New York Times 1997; June 24: 1-6.

30. Peto R, Lopez A, Boreham J, Thun M, Heath C. Mortality from tobacco in developed countries: indirect estimates from national vital statistics. Lancet 1992; 339: 1268-1278.

31. Riphahn RT, Zimmermann KF. The transitions' mortality crisis in East Germany. Research for Action 42. The United Nations University. World Institute for Development Economics Research, 1997.

32. Rzuć palenie razem $z$ nami [Let's stop smoking together]. Fundacja „Promocja zdrowia”, Warszawa 2004.

33. Unal B, Critchley JA, Capewell S. Explaining the decline in coronary heart disease mortality in England and Wales between 1981 and 2000. Circulation 2004; 109: 1101-1107.

34. Varasovszky Z, Bain C, McKee M. Alcohol related mortality in Poland and Hungary: differences and similarities. J Epidemiol Comm Health 1997; 51: 167-171.

35. World Bank. The transition in Central and Eastern Europe. World Bank Technical Paper No. 341. World Bank, Washington 1996.

36. Zatoński M, Zatoński WA, Przewoźniak K, Jaworski M. The significance and impact of the Polish Anti-tobacco Law. J Health Inequal 2016; 2: 32-35.

37. Zatoński M, Zatoński WA, Wojtyła A. Premature mortality: Europe's persisting Iron Curtain? J Health Inequal 2016; 2: 3-6.

38. Zatoński M. Marking the $20^{\text {th }}$ anniversary of the Polish Anti-tobacco Law. J Health Inequal 2016; 2: 110.

39. Zatoński M. Poland's anti-tobacco advocacy - a historical outline. J Health Inequal 2016; 2: 26-31.

40. Zatoński M. Report from the Conference on Smoke-free Poland, Ministry of Health, Warsaw, Poland, 18 May 2016. J Health Inequal 2016; 2: 111-119.

41. Zatoński M. Report from the witness seminar on tobacco control policy in Poland, Chief Sanitary Inspectorate, Warsaw, Poland, 31 May 2016. J Health Inequal 2016; 2: 120-127.

42. Zatoński $W$ and the HEM Project team. Closing the health gap in European Union. Cancer Center and Institute of Oncology, Warszawa 2008.

43. Zatoński W, Becher H, Lissowska J, Wahrendorf J. Tobacco, alcohol, and diet in the etiology of laryngeal cancer: a population-based case-control study. Cancer Causes Control 1991; 2: 3-10.

44. Zatoński W, Becker N. Atlas of cancer mortality in Poland 1975-1979. Springer-Verlag, Berlin 1988.

45. Zatoński W, Bhala N. Changing trends of diseases in Eastern Europe: Closing the gap. Public Health 2012; 126: 248-252.

46. Zatoński W, Campos H, Willet W. Rapid declines in coronary heart disease mortality in Eastern Europe are associated with increased consumption of oils rich in alpha-linolenic acid. Eur J Epidemiol 2008; 23: 3-10.

47. Zatoński W, Jurgielaniec S, Przewoźniak K. It can be done: the battle on Tobacco Control Law in Poland. In: Tobacco - the growing epidemic. Abstract book. The $10^{\text {th }}$ World Conference on Tobacco or Health, 24-28 August 1997, Beijing 1997: 70.

48. Zatoński W, McMichael AJ, Powles JW. Ecological study of reason for sharp decline in mortality from ischaemic hearth disease in Poland since 1991. Br Med J 1998; 316: 1047-1051. 
49. Zatoński W, Przewoźniak K, Sulkowska U, et al. Tobacco smoking in countries of the European Union. Ann Agr Env Med 2012; 2: 181-192.

50. Zatoński W, Pukkala E, et al. Atlas of cancer mortality in Poland 1986-1990. Centrum Onkologii - Instytut, Oficyna Wydawnicza Interspar, Warszawa 1993.

51. Zatoński W, Smans M, Tyczyński J, Boyle P (eds.). Atlas of cancer mortality in Central Europe. IARC Scientific Publications No. 134. International Agency for Research on Cancer, Lyonn 1995.

52. Zatoński W, Zatoński M. Sytuacja zdrowotna [Health situation]. In: Dzieje medycyny w Polsce. [History of Medicine in Poland]. Vol. 3. Lata 1944-1989. Noszczyk W. Wydawnictwo Lekarskie PZWL, Warszawa 2016.

53. Zatoński W, Zatoński M. Cytisine versus nicotine for smoking cessation. N Engl J Med 2015; 372: 1072.

54. Zatoński W. Alcohol and health: what is good for the French may not be for the Russians. J Epidemiol Community Health 1998; 52: 766-767.

55. Zatoński W. Decreasing smoking in Poland: The importance of a comprehensive governmental policy. J Clin Psychiatry Monograph 2003; 18: 74-82.

56. Zatoński W. Droga do zdrowia. Historia przeciwdziałania chorób odtytoniowych w Polsce [Road to the health. History of tobacco control in Poland]. Fundacja "Promocja Zdrowia", Warszawa 2004.

57. Zatoński W. Jak rzucić palenie [How to stop smoking]. Fundacja „Promocja Zdrowia”, Warszawa 2007.

58. Zatoński W. Konsensus dotyczący rozpoznania i leczenia zespołu uzależnienia od tytoniu [Consensus on diagnosis and treatment of tobacco dependence]. Wydawnictwo Medycyna Praktyczna, Kraków 2007.

59. Zatoński W. The dynamics of mortality in Poland. In: Health and mortality issues of global concern. Population Division, United Nations Secretariat, New York 1999; 227-261.

60. Zatoński W. The health of the Polish population. Public Health Rev Israel 1995; 23: 139-156.

61. Zatoński W. Tobacco smoking in central European countries: Poland. In: Tobacco and public health: science and policy. Boyle P, Gray N, Henningfield J, Sefrin J, Zatoński W (eds.). Oxford University Press, New York 2004: 235-252.

62. Zatoński WA, Boyle P. Health transformations in Poland after 1988. J Epidemiol Biostat 1996; 4: 183-197.

63. Zatoński WA, Sulkowska U, Mańczuk M, et al. Liver cirrhosis mortality in Europe, with special attention to Central and Eastern Europe. Eur Addict Res 2010; 16: 193-201.

64. Zatoński WA, Willet W. Changes in dietary fat and declining coronary heart disease in Poland: population based study. BMJ 2005; 331: 187-188

65. Zatoński WA, Zatoński M. Democracy is healthier - health in Poland in the late 1980s and 1990s. J Health Inaqual 2016; 2: 17-24.

66. Zatoński WA, Zatoński M. Health in the Polish People’s Republic. J Health Inequal 2016; $2: 7-16$.

67. Zatoński WA, Aaro LE, Samdal O, Mazur J. Smoking- or nicotine-free generation, or both? What should be the public health priority? J Health Inequal 2016; 2: 105-108.

68. Zatoński WA. Nowotwory złośliwe w Polsce [Cancer in Poland] Centrum Onkologii - Instytut, Warszawa 1993. 